\title{
ANALISIS FAKTOR-FAKTOR DOMINAN YANG MEMPENGARUHI EKONOMI RUMAH TANGGA PETANI PADI SAWAH DI KECAMATAN KUOK KABUPATEN KAMPAR
}

\author{
Analysis of the Dominant Factors That Influence Economic Paddy Farming \\ Households in the District Of Kampar Kuok \\ Elpi Evi, Djaimi Bakce dan Jum'atri Yusri \\ Agribusiness Department, Faculty of Agricultural, University of Riau, Pekanbaru, Indonesia \\ Email: elpievi_barasa@yahoo.com \\ [Diterima: November 2016; Disetujui: Maret 2017]
}

\begin{abstract}
The purpose of the research for analyzing determination factors that affect household economic of farmers against the production, allocation of work time, incomes, and expenses of field paddy household in the subdistrict of Kuok, district of Kampar. The analysis model used is the simultaneous equivalent model with Two-Stage Least Square (2SLS) method. The result of research concludes that: firstly, determination factors which affect production are harvest area and a total of allocation of working time in farming but there is no responsive variable. Secondly, the determining factors that affect the allocation of working time are the income in farming, allocation of out working in farming, labor force, income non-paddy farming, allocation of working time in farming, however only production variable which is responsive. Thirdly, determination factors that affect income nonpaddy farming are allocation of non-working time, labor force, farmer's age, and the experiences of farmer however, there is no responsive variable. Fourthly, determination factors that affect consumption are total of farmer's income and the number of a household member, investment of education and savings, but only income total of the farmer is responsive can affect consumption.
\end{abstract}

Keywords: Allocation of working time, Income, Expenditure, Household of farmers

\begin{abstract}
ABSTRAK
Penelitian ini bertujuan untuk menganalisis faktor-faktor dominan yang mempengaruhi ekonomi rumah tangga petani terhadap produksi, alokasi waktu kerja, pendapatan, dan pengeluaran rumah tangga padi sawah di Kecamatan Kuok Kabupaten Kampar. Model analisis yang digunakan adalah model persamaan simultan dengan metode Two Stage Least Square (2 SLS). Hasil penelitian menyimpulkan bahwa: pertama, faktor-faktor dominan yang mempengaruhi produksi adalah luas panen padi sawah dan total alokasi waktu kerja dalam usahatani, namun tidak ada peubah yang responsif. Kedua, faktor-faktor dominan yang mempengaruhi alokasi waktu kerja adalah pendapatan dalam usahatani, alokasi waktu kerja luar usahatani, jumlah angkatan kerja petani, pendapatan luar usahatani, alokasi waktu kerja dalam usahatani, namun hanya peubah produksi yang responsif. Ketiga, faktor-faktor dominan yang mempengaruhi pendapatan luar usahatani yaitu alokasi waktu kerja luar usahatani, jumlah angkatan kerja petani, umur petani dan pengalaman kerja petani, namun tidak ada peubah yang responsif. Keempat, faktor-faktor dominan yang mempengaruhi konsumsi adalah pendapatan total petani dan jumlah anggota rumah tangga, investasi pendidikan dan tabungan, hanya peubah pendapatan total petani yang responsif.
\end{abstract}

Kata kunci: Alokasi waktu kerja, Pendapatan, Pengeluaran, Rumah tangga petani 


\section{PENDAHULUAN}

Padi merupakan tanaman pangan yang penting bagi masyarakat Indonesia. Salah satu wilayah penghasil padi di Provinsi Riau adalah Kabupaten Kampar. Kecamatan Kuok merupakan wilayah dengan areal panen padi sawah terluas di Kabupaten Kampar yaitu 940 Ha dengan produksi mencapai 4.248,8 Ton pada tahun 2014 (Badan Pusat Statistik Kampar, 2015). Keadaan ini menunjukkan bahwa terdapat rumah tangga petani yang mengalokasikan waktunya untuk berusahatani padi sawah. Usahatani padi sawah yang dilakukan oleh rumah tangga petani masih bersifat subsisten dengan lahan yang sempit. Rata-rata kepemilikan lahan yang sempit menyebakan hampir seluruh rumah tangga petani padi sawah di Kecamatan Kuok hanya mengusahakan padi untuk memenuhi kebutuhan beras keluarga. Hal ini menyebabkan usahatani padi sawah bukan satu-satunya sumber pendapatan rumah tangga petani. Permasalahan sempitnya lahan yang diusahakan petani menyebabkan terjadinya peningkatan alokasi waktu kerja suami, isteri, dan anggota rumah tangga lainnya pada non usahatani untuk meningkatkan pendapatan rumah tangga.

Menurut Becker (1976), rumah tangga melakukan kegiatan produksi dan konsumsi secara simultan. Rumah tangga sebagai produsen memiliki sumberdaya waktu untuk bekerja, sedangkan sebagai konsumen, dalam mengkonsumsi memperoleh kepuasan bukan hanya dari barang dan jasa yang diperoleh tetapi juga dari komoditi yang dihasilkan rumah tangga. Bryant (1990) mengemukakan tujuan dari setiap rumah tangga dari konteks ekonomi yaitu mencapai kepuasan (satisfaction) dan kegunaan (utility) berupa materi dan non materi. Untuk memenuhi tujuan tersebut maka anggota rumah tangga sebagai produsen maupun konsumen harus mampu membuat keputusan yang tepat baik dalam aktivitas produksi, alokasi waktu kerja yang akan mempengaruhi pendapatan dan pengeluaran rumah tangganya.

Pada kenyataannya perilaku rumah tangga petani sangat mempengaruhi dalam pengambilan keputusan baik dari produksi, alokasi waktu kerja, pendapatan dan pengeluaran rumah tangga tersebut. Rumah tangga petani padi tidak dapat dilihat hanya sebagai produsen karena pada kenyataannya setiap rumah tangga petani dapat menjalankan tiga peran sekaligus, yaitu sebagai produsen, konsumen dan penyedia tenaga kerja. Rumah tangga sebagai produsen akan memproduksi lebih banyak barang yang harganya relatif mahal dan lebih sedikit memproduksi barang yang harganya murah untuk mendapatkan keuntungan. Sebagai konsumen, rumah tangga akan mengkonsumsi lebih banyak barang yang harganya relatif murah dan mengkonsumsi lebih sedikit barang yang harganya relatif mahal (Lipsey et al, 1995).

Setiap anggota keluarga dalam rumah tangga dipengaruhi faktor umur, tingkat pendidikan atau keahlian yang dimiliki anggota keluarga lain hal dalam menentukan alokasi waktu dalam usahanya. Selain itu kebijakan pemerintah dalam penetapan harga dan upah akan berdampak terhadap pengambilan keputusan ekonomi rumah tangga petani.

Berbagai permasalahan yang terjadi dalam usahatani padi sawah akan berpengaruh terhadap perolehan produksi, alokasi waktu kerja, pendapatan, dan pengeluaran konsumsi rumah tangga petani sehingga perlu dilakukan analisis ekonomi rumah tangga terkait kebijakan yang akan diambil pemerintah untuk pembangunan ekonomi di negara tersebut (Widodo, 2011). Bertitik tolak dari pemikiran tersebut maka penelitian ini dilaksanakan bertujuan menganalisis faktor-faktor dominan yang mempengaruhi keputusan ekonomi rumah tangga terhadap produksi, alokasi waktu kerja, pendapatan dan pengeluaran rumah tangga petani padi di Kecamatan Kuok Kabupaten Kampar serta merumuskan implikasi kebijakan pemerintah terhadap pengembangan usahatani padi sawah di Kecamatan Kuok Kabupaten Kampar.

\section{METODOLOGI PENELITIAN}

Penelitian ini dilaksanakan pada bulan September sampai bulan Oktober 2016 di Kecamatan Kuok Kabupaten Kampar, Provinsi Riau. Lokasi penelitian ditentukan secara sengaja dengan pertimbangan bahwa desa tersebut adalah sentra padi sawah. Tiga desa sentra padi sawah di Kecamatan Kuok yaitu Desa Kuok, Desa Pulau Jambu dan Desa Empat Balai.

Data penelitian menggunakan data primer yang diperoleh melalui wawancara langsung dengan petani padi sawah dengan menggunakan kuisioner yang telah disusun. Kuesioner penelitian yang digunakan terdiri dari pertanyaan meliputi: aspek produksi, aspek 
alokasi waktu kerja, pendapatan dan pengeluaran rumah tangga petani padi sawah.

Populasi yang diambil dalam penelitian ini adalah rumah tangga petani padi sawah di Kecamatan Kuok. Setiap desa diambil 15 orang petani sebagai sampel, sehingga jumlah sampel pada penelitian ini sebesar 45 sampel. Menurut Teorema batas sentral (Central Limit Theorem), untuk ukuran sampel cukup besar $(\mathrm{n} \geq 30$ ), ratarata sampel akan terdistribusi disekitar rata-rata populasi yang mendekati distribusi normal (Cooper dan Emory, 1996). Dengan demikian, pengambilan sampel sebanyak 45 petani padi sawah sudah memenuhi batas minimum sampel (30 sampel) yang dapat digunakan untuk menduga karakteristik (variasi) dari populasi.

Dalam menganalisis faktor- faktor domianan yang mempengaruhi ekonomi rumah tangga petani padi sawah, terdapat beberapa tahapan analisis yang harus dilalui yaitu spesifikasi model, identifikasi model, estimasi model dan perhitungan elastisitas. Adapun tahapan tersebut antara lain:

\section{Spesifikasi Model}

Spesifikasi model dilakukan untuk melihat hubungan antara peubah- peubah yang dimasukkan ke dalam model, yang selanjutnya diformulasikan ke dalam sejumlah persamaan strruktural dan identitas. Persamaan tersebut terdiri dari 11 persamaan struktural dan 6 persamaan identitas dengan 17 peubah endogen dan 8 peubah eksogen. Spesifikasi model terdiri dari 4 blok yaitu blok produksi, blok alokasi waktu kerja, blok pendapatan dan pengeluaran rumah tangga petani padi sawah.

\section{Identifikasi Model}

Model yang dibangun harus diindentifikasi terlebih dahulu sehingga model dapat diestimasi. Identifikasi model dilakukan berdasarkan order condition dengan rumus: (K-M) $\geq(\mathrm{G}-1)$ dimana: $\mathrm{K}=$ Total peubah dalam model (peubah endogen dan peubah determinan), $\mathrm{M}=\mathrm{Jumlah}$ peubah endogen dan eksogen yang dimasukkan kedalam suatu persamaan tertentu dalam model, $\mathrm{G}=$ Total persamaan (jumlah peubah endogen). Kriteria identifikasi model dengan menggunakan order condition dinyatakan sebagai berikut: Jika $(\mathrm{K}-\mathrm{M})=(\mathrm{G}-1)$, maka persamaan dalam model dinyatakan teridentifikasi secara tepat (exactly identified); Jika $(\mathrm{K}-\mathrm{M})<(\mathrm{G}-1)$, maka persamaan dalam model dikatakan tidak teridentifikasi (unidentified); Jika (K-M) > (G1), maka persamaan dalam model dikatakan teridentifikasi berlebih (overidentified) (Koutsoyiannis, 1977; Interligator, 1978). Hasil identifikasi model ekonomi rumah tangga petani padi sawah menunjukan bahwa terdapat 17 peubah endogen dan 8 peubah eksogen. Total peubah dalam model (K) adalah 25 peubah. Hal ini menunjukkan bahwa setiap persamaan dalam model ekonomi rumah tangga petani padi sawah teridentifikasi berlebih (over identified).

\section{Estimasi}

Berdasarkan hasil identifikasi model diatas, maka metode estimasi yang baik untuk digunakan adalah metode Two Stage Least Square (2 SLS). Dalam penelitian juga dilakukan uji $F$ dan uji t untuk melihat pengaruh peubah-peubah eksogen secara individual dalam menerangkan variasi peubah endogennya. Dalam penelitian ini taraf nyata yang digunakan sampai pada batas 20 persen.

\section{Elastisitas}

Setelah hasil pendugaan model diperoleh, maka dihitunglah elastisitas dari variabelvariabel yang memiliki nilai dugaan yang berbeda nyata sama dengan nol pada taraf sampai dengan 20 persen. Konsep elastisitas digunakan untuk mendapatkan nilai kuantitatif dari respon suatu fungsi terhadap faktor-faktor yang mempengaruhinya. Nilai elastisitas digunakan untuk melihat apakah peubah-peubah yang mempengaruhi pada model berpengaruh secara positif atau negatif dan apakah peubahpeubah yang mempengaruhi pada model bersifat responsif atau tidak terhadap peubah yang dipengaruhinya. Jika nilai elastisitas yang diperoleh besar dari 1 maka peubah yang dipengaruhi bersifat responsif terhadap perubahan peubah yang mempengaruhinya, sebaliknya, jika nilai elastisitas yang diperoleh kecil dari 1 maka peubah yang dipengaruhi bersifat tidak responsif terhadap perubahan peubah yang mempengaruhinya. Untuk menghitung nilai elastisitas dapat dirumuskan sebagai berikut (Sukirno, 2002):

$$
\mathrm{E}_{\mathrm{SR}}=\frac{\partial Y}{\partial X}+\frac{\bar{X}}{\bar{Y}}=\mathrm{b} \frac{\bar{X}}{\bar{Y}}
$$


Dimana:

$\mathrm{E}_{\mathrm{SR}}=$ Elastisitas jangka pendek,

$\mathrm{b}=$ Parameter dugaan dari peubah eksogen,

$\bar{X}=$ Rata-rata peubah eksogen,

$\bar{Y}=$ Rata-rata peubah endogen (Mean Predicted hasil validasi model)

\section{HASIL DAN PEMBAHASAN}

Hasil pendugaan atas 17 persamaan pada model ekonomi rumah tangga petani padi sawah di Kecamatan Kuok Kabupaten Kampar dapat dilihat pada Tabel 1. Nilai koefisien determinasi pada model ekonomi rumah tangga petani padi sawah di Kecamatan Kuok berkisar antara 0,50220 sampai 0,97147 dengan statistik uji $\mathrm{F}$ berkisar antara 10,09 sampai 395,44 dan berbeda nyata dengan nol pada taraf 20 persen.
Hasil koefisien determinasi $\left(\mathrm{R}^{2}\right)$ tersebut menunjukkan bahwa peubah-peubah eksogen yang dimasukkan pada setiap persamaan model ekonomi rumah tangga petani padi sawah pada penelitian ini sudah mampu menjelaskan dengan baik peubah endogennya.

Berdasarkan hasil olah data dapat dinyatakan bahwa koefisien-koefien penduga serta statistik $\mathrm{F}$ dan $\mathrm{t}$ dalam penelitian ini secara keseluruhan masih dapat dipercaya. Semua tanda dan parameter dugaan dalam model sudah sesuai dengan teori maupun logika ekonomi. Sehingga dapat disimpulkan bahwa model yang dibangun mampu untuk menjelaskan faktorfaktor dominan yang mempengaruhi ekonomi rumah tangga yang meliputi produksi, alokasi waktu kerja, pendapatan dan pengeluaran rumah tangga petani padi sawah di Kecamatan Kuok.

Tabel 1. Hasil Dugaan Parameter dan Elastisitas

\begin{tabular}{|c|c|c|c|c|c|c|}
\hline \multirow[t]{2}{*}{ No } & Persamaan & Notasi & $\begin{array}{c}\text { Parameter } \\
\text { Dugaan }\end{array}$ & TValue & $\operatorname{Pr}>|t|$ & \multirow[t]{2}{*}{ Elastisitas } \\
\hline & Blok Produksi & & & & & \\
\hline \multirow[t]{7}{*}{1.} & Produksi & Q & & & & \multirow{5}{*}{0,2470} \\
\hline & Intercept & - & $-266,612$ & $-1,09$ & 0,2461 & \\
\hline & $\begin{array}{l}\text { Luas Panen Padi } \\
\text { Sawah }\end{array}$ & LPPS & 2510,66 & 3,47 & $<.0001$ & \\
\hline & $\begin{array}{l}\text { Total Tenaga } \\
\text { Kerja Dalam } \\
\text { Usaha }\end{array}$ & TTKU & 4,066757 & 3,96 & 0,1306 & \\
\hline & $\begin{array}{l}\text { Biaya Sarana } \\
\text { Produksi }\end{array}$ & BSP & 4,373550 & 4,44 & 0,4925 & \\
\hline & & \multicolumn{2}{|c|}{$R^{2}=0,94277$} & FValue $=225,15$ & \multicolumn{2}{|c|}{$\mathrm{Pr}>\mathrm{F}=<, 0001$} \\
\hline & Blok Curahan Dalar & Kerja & & & & \\
\hline \multirow[t]{7}{*}{2.} & $\begin{array}{l}\text { Curahan Kerja } \\
\text { Dalam Usaha }\end{array}$ & CKDU & & & & \\
\hline & Intercept & - & 314,3079 & 8,43 & $<, 0001$ & \\
\hline & $\begin{array}{l}\text { Pendapatan Dalam } \\
\text { Usaha }\end{array}$ & PPD & 0,0000019 & 1,55 & 0,1301 & 0,0656 \\
\hline & $\begin{array}{l}\text { Curahan Kerja } \\
\text { Luar Usaha }\end{array}$ & CKLU & $-0,77895$ & $-5,54$ & $<, 0001$ & $-0,7789$ \\
\hline & $\begin{array}{l}\text { Biaya Sarana } \\
\text { Produksi }\end{array}$ & BSP & 0,0000035 & 1,14 & 0,2599 & 0,0623 \\
\hline & $\begin{array}{l}\text { Angkatan Kerja } \\
\text { Petani }\end{array}$ & AKP & 8,786768 & 1,74 & 0,0892 & 0,1179 \\
\hline & & \multicolumn{2}{|c|}{$\mathrm{R}^{2}=0,71035$} & FValue $=24,52$ & \multicolumn{2}{|c|}{$\operatorname{Pr}>\mathrm{F}=<.0001$} \\
\hline \multirow[t]{6}{*}{3.} & $\begin{array}{l}\text { Tenaga Kerja Luar } \\
\text { Keluarga }\end{array}$ & TKLP & & & & \multirow{5}{*}{1,8111} \\
\hline & Intercept & - & $-14,9161$ & $-1,7$ & 0,0966 & \\
\hline & Produksi & $\mathrm{Q}$ & 0,0154 & 8,81 & $<, 0001$ & \\
\hline & $\begin{array}{l}\text { Angkatan Kerja } \\
\text { Petani }\end{array}$ & $\mathrm{AKP}$ & $-1,3497$ & $-0,57$ & 0,5729 & \\
\hline & $\begin{array}{l}\text { Pengalaman Kerja } \\
\text { Petani }\end{array}$ & PKP & 0,1989 & 0,96 & 0,3405 & \\
\hline & & & $=0,6543$ & FValue $=25,87$ & $\operatorname{Pr}>\mathrm{F}=$ & \\
\hline
\end{tabular}




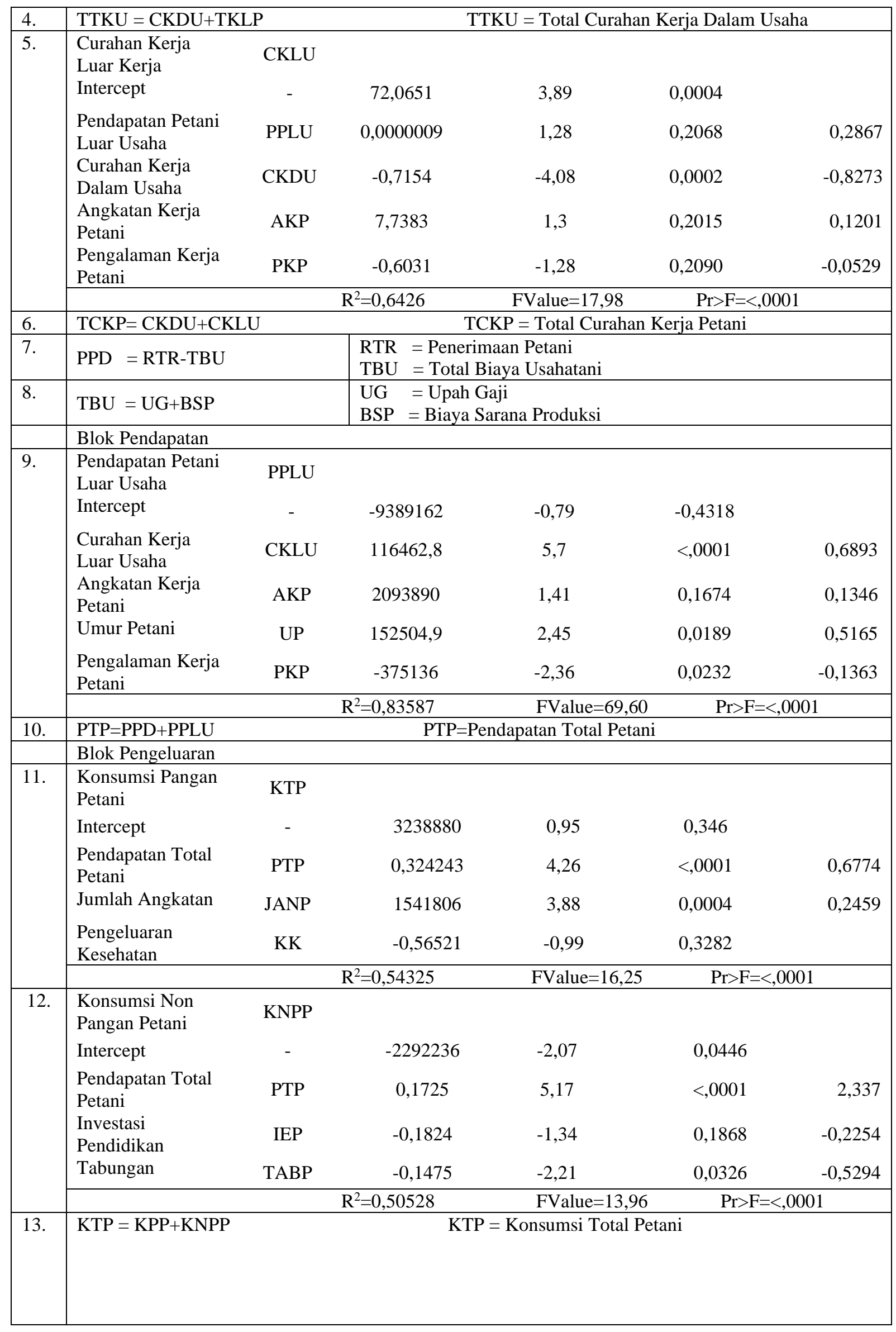




\begin{tabular}{|c|c|c|c|c|c|c|}
\hline \multirow[t]{5}{*}{14.} & $\begin{array}{l}\text { Investasi } \\
\text { Pendidikan }\end{array}$ & IEP & & & \\
\hline & Intercept & - & -1463042 & $-0,58$ & 0,5632 & \\
\hline & $\begin{array}{l}\text { Pendapatan Total } \\
\text { Petani }\end{array}$ & PTP & 0,054812 & 1,19 & 0,2397 & 0,6009 \\
\hline & $\begin{array}{l}\text { Jumlah Anak } \\
\text { Sekolah }\end{array}$ & JASP & 1961990 & 6,51 & $<, 0001$ & 0,7001 \\
\hline & & \multicolumn{2}{|c|}{$R^{2}=0,51383$} & FValue $=22,19$ & \multicolumn{2}{|c|}{$\operatorname{Pr}>\mathrm{F}=<, 0001$} \\
\hline \multirow[t]{6}{*}{15.} & Investasi Usaha & IUP & & & & \\
\hline & Intercept & - & -12790000 & $-2,21$ & 0,0325 & \\
\hline & $\begin{array}{l}\text { Pendapatan Total } \\
\text { Petani }\end{array}$ & PTP & 0,172904 & 1,67 & 0,1035 & 0,2403 \\
\hline & $\begin{array}{l}\text { Luas Panen Padi } \\
\text { Sawah }\end{array}$ & LPPS & 59859435 & 28,1 & $<.0001$ & 1,1579 \\
\hline & $\begin{array}{l}\text { Investasi } \\
\text { Pendidikan }\end{array}$ & IEP & $-0,50807$ & $-1,48$ & 0,1475 & $-0,0644$ \\
\hline & & \multicolumn{2}{|c|}{$\mathrm{R}^{2}=0,96659$} & FValue $=395,44$ & \multicolumn{2}{|c|}{$\operatorname{Pr}>\mathrm{F}=<, 0001$} \\
\hline \multirow[t]{7}{*}{16.} & $\begin{array}{l}\text { Pengeluaran } \\
\text { Rekreasi }\end{array}$ & KRP & & & \multirow{2}{*}{\multicolumn{2}{|c|}{0,2894}} \\
\hline & Intercept & - & -1329846 & $-1,07$ & & \\
\hline & $\begin{array}{l}\text { Pendapatan Total } \\
\text { Petani }\end{array}$ & PTP & 0,6521 & 7,26 & $<, 0001$ & 13,3935 \\
\hline & $\begin{array}{l}\text { Investasi } \\
\text { Pendidikan }\end{array}$ & IEP & $-0,7912$ & $-5,26$ & $<, 0001$ & $-1,4821$ \\
\hline & $\begin{array}{l}\text { Konsumsi Total } \\
\text { Petani }\end{array}$ & KTP & $-0,6001$ & $-4,87$ & $<, 0001$ & $-6,8096$ \\
\hline & Tabungan & TABP & $-0,6597$ & $-6,16$ & $<, 0001$ & $-3,5891$ \\
\hline & & \multicolumn{2}{|c|}{$\mathrm{R}^{2}=0,7758$} & FValue $=34,61$ & \multicolumn{2}{|c|}{$\operatorname{Pr}>\mathrm{F}=<, 0001$} \\
\hline \multirow[t]{7}{*}{17.} & Tabungan & TABP & & & & \\
\hline & Intercept & - & 880957,7 & 0,57 & \multicolumn{2}{|l|}{0,5732} \\
\hline & $\begin{array}{l}\text { Pendapatan Total } \\
\text { Petani }\end{array}$ & PTP & 0,9289 & 22,14 & $<, 0001$ & 3,5063 \\
\hline & $\begin{array}{l}\text { Konsumsi Total } \\
\text { Petani }\end{array}$ & KTP & $-0,9367$ & $-12,44$ & $<, 0001$ & $-1,9530$ \\
\hline & $\begin{array}{l}\text { Investasi } \\
\text { Pendidikan }\end{array}$ & IEP & $-1,2249$ & $-16,99$ & $<, 0001$ & $-0,4216$ \\
\hline & $\begin{array}{l}\text { Pengeluaran } \\
\text { Rekreasi }\end{array}$ & KRP & $-1,0575$ & $-6,38$ & $<, 0001$ & $-0,1943$ \\
\hline & & \multicolumn{2}{|c|}{$\mathrm{R}^{2}=0,97147$} & FValue $=304,56$ & \multicolumn{2}{|c|}{$\operatorname{Pr}>\mathrm{F}=<, 0001$} \\
\hline
\end{tabular}

Hasil pendugaan parameter model ekonomi rumah tangga petani padi sawah di Kecamatan Kuok menunjukkan bahwa produksi padi sawaah dipengaruhi secara positif tetapi tidak responsif oleh luas panen padi sawah dan total tenaga kerja dalam usahatani. Jika dilihat dari nilai elastisitasnya peubah luas panen padi sawah adalah yang paling respon dari pada peubah yang lain. Hal ini menunjukkan bahwa luas lahan sangat mempengaruhi produksi padi sawah.

Jika dilihat dari aspek alokasi waktu kerja dapat dinyatakan bahwa: Pertama, curahan kerja dalam usahatani padi sawah dipengaruhi secara positif namun tidak responsif oleh pendapatan rumah tangga petani padi sawah dalam usahatani dan angkatan kerja petani. Sedangkan curahan kerja luar usaha mempengaruhi negatif dan tidak responsif terhadap perubahan curahan kerja dalam usaha. Kedua, penggunaan tenaga kerja luar keluarga dipengaruhi secara positif dan responsif oleh produksi padi sawah. Ketiga, curahan kerja luar usaha dipengaruhi secara positif tetapi tidak responsif oleh pendapatan rumah tangga di luar usahatani, curahan kerja dalam usahatani, angkatan kerja rumah tangga petani dan pengalaman kerja petani. Dapat dinyatakan bahwa faktor utama yang penentu keputusan rumah tangga untuk mengalokasikan waktu kerja adalah besarnya produksi padi 
sawah yang dihasilkan. Apabila produksi petani meningkat maka akan meningkatkan penggunaan tenaga kerja luar keluarga karena petani memiliki waktu yang terbatas dalam mencurahkan waktu kerja di dalam dan luar usahatani padi sawah.

Jika dilihat dari aspek pendapatan rumah tangga menunjukkan bahwa pendapatan petani diluar usahatani padi sawah dipengaruhi secara positif namun tidak responsif oleh curahan kerja rumah tangga petani diluar usaha, jumlah angkatan kerja dan umur petani sedangkan peubah pengalaman kerja petani mempengaruhi secara negatif dan tidak responsif. Jika dilihat dari aspek pengeluaran dapat dinyatakan bahwa: Pertama, konsumsi pangan dipengaruhi secara positif tetapi tidak responsif oleh pendapatan total petani dan jumlah anggota keluarga petani. Kedua, konsumsi non pangan dipengaruhi secara positif dan responsif oleh pendapatan total rumah tangga petani sedangkan, investasi pendidikan dan tabungan mempengaruhi secara negatif dan tidak responsif. Ketiga, investasi pendidikan dipengaruhi secara positif dan tidak responsif oleh pendapatan total rumah tangga petani dan jumlah anak sekolah. Keempat, investasi usahatani padi sawah dipengaruhi secara positif oleh pendapatan total petani dan luas panen padi sawah sedangkan investasi pendidikan mempengaruhi secara negatif. Namun hanya luas panen padi sawah yang mempengaruhi investasi usahatani secara responsi. Kelima, pengeluaran rekreasi dipengaruhi secara positif dan responsif oleh pendapatan total rumah tangga petani sedangkan investasi pendidikan, konsumsi total petani dan tabungan berpengaruh negatif dan responsif. Keenam, tabungan dipengaruhi secara positif dan responsif oleh pendapatan total rumah tangga petani namun dipengaruhi secara negatif tetapi tidak responsif oleh konsumsi total rumah tangga petani dan investasi pendidikan dan pengeluaran rekreasi. Dengan demikian, pendapatan total rumah tangga petani sangat mempengaruhi pengeluaran konsumsi rumah tangga petani.

\section{KESIMPULAN}

1. Pada aspek produksi faktor-faktor dominan yang mempengaruhi adalah luas panen padi sawah dan total tenaga kerja dalam usahatani, namun tidak ditemukan faktor yang mempengaruhi secara responsif.
2. Pada aspek alokasi waktu kerja yaitu: Pertama, faktor dominan yang mempengaruhi curahan kerja dalam usahatani adalah pendapatan dalam usaha, curahan kerja luar usaha dan angkatan kerja petani. Kedua, pada persamaan penggunaan tenaga kerja luar keluarga dalam usahatani dipengaruhi oleh produksi. Ketiga, faktor dominan yang mempengaruhi curahan kerja luar usahatani adalah pendapatan luar usahatani, curahan kerja dalam usahatani, angkatan kerja petani dan pengalaman kerja petani.

3. Pada aspek pendapatan, faktor dominan yang mempengaruhi adalah curahan kerja luar usaha, angkatan kerja petani, umur petani dan pengalaman kerja petani. Pada aspek pengeluaran yaitu: Pertama, faktor dominan yang mempengaruhi pengeluaran konsumsi pangan adalah pendapatan total petani dan jumlah anggota rumah tangga petani. Kedua, faktor dominan yang mempengaruhi pengeluaran konsumsi non pangan adalah pendapatan total petani, investasi pendidikan dan tabungan rumah tangga petani. Ketiga, investasi pendidikan dipengaruhi oleh pendapatan total petani dan jumlah anak. Keempat, investasi usahatani dipengaruhi oleh pendapatan total petani, luas panen padi sawah dan investasi pendidikan. Kelima pengeluaran rekreasi dipengaruhi oleh pendapatan total petani, invetasi pendidikan, konsumsi total petani dan tabungan. Keenam, tabungan dipengaruhi oleh oleh pendapatan total petani, konsumsi total petani, investasi pendidikan dan pengeluaran petani.

\section{DAFTAR PUSTAKA}

Badan Pusat Statistik. 2015. Kampar dalam Angka 2015. Badan Pusat Statistik Kabupaten Kampar, Kampar.

Becker, G.S. 1976. The Economic Approach to Human Behaviour. The University of Chicago Press, London.

Bryant, W.K. (1990). The Economic Organization of The Household. United States of America: Cambridge University Press.

Cooper, D dan C William Emory. 1996. Metode Penelitian Bisnis. Erlangga, Jakarta. 
Intriligator, M.D. 1978. Econometric Model, Techniques and Applications. Prentice Hall Inc., New Jersey.

Koutsoyiannis, A. 1977. Theory of Econometrics. Harper and Row Publisher Inc., New York.

Lipsey. R.G., P.N. Courant, D.D. Purpis dan P.O. Steiner. 1995. Pengantar EkonomiMikro (Terjemahan). Binarupa Aksara, Jakarta.

Sukirno, S. 2002. Pengantar Teori Mikroekonomi. Raja Grafindo Persada, Jakarta.

Widodo, Sri. 2011. Konsep, Teori dan Paradigma Pembangunan Pertanian. Gadjah Mada University Press, Yogya. 
